\title{
Return projects in the Spanish Republican exile's political cultures
}

\author{
Jorge de Hoyos Puente \\ Departamento de Historia Contemporánea. Universidad Nacional de Educación a Distancia. Senda del Rey 7, 5 planta, 28040 Madrid. \\ e-mail: jdehoyos@geo.uned.es \\ ORCID iD: http://orcid.org/0000-0002-7759-9053
}

Submitted: 18 January 2017. Accepted: 6 February 2017

\begin{abstract}
This paper presents the political projects variety issued from the Spanish Republican exile. Its aim is to analyse the reasons of disagreement that took place throughout forty years of Franco's opposition. Focusing on the political cultures' study it can be confirmed a wade range of speeches and political imaginaries that shaped Spanish left-wing groups on the twentieth century Spanish longest exile.
\end{abstract}

KEYWORDS: Spanish Republican exile; Speeches; Political cultures; Spanish left-wing forces; $20^{\text {th }}$ century.

Citation / Cómo citar este artículo: Hoyos Puente, Jorge de (2018) "Return projects in the Spanish Republican exile's political cultures". Culture \& History Digital Journal, 7 (1): e002. https://doi.org/10.3989/chdj.2018.002

RESUMEN: Proyectos de retorno en las culturas politicas del exilio republicano.- Este artículo analiza los diversos proyectos políticos surgidos en el exilio republicano. En él tratamos de presentar las razones de los desencuentros producidos durante cuarenta años de oposición al franquismo. Desde el estudio de las culturas políticas podemos comprobar la diversidad de los discursos y los imaginarios políticos que conformaron la izquierda española en el exilio español más largo del siglo XX.

PALABRAS CLAVE: Exilio republicano; Discursos; Culturas políticas; Izquierda española; Siglo XX.

Copyright: (C) 2018 CSIC. This is an open-access article distributed under the terms of the Creative Commons Attribution 4.0 International (CC BY 4.0) License.

\section{THE COMPLEXITY OF THE SPANISH EXILE AND ITS POLITICAL CULTURES}

Attending to its volume and complexity the 1939 Spanish republican exile remains even seventy five years later an endless working source for historians. Despite the remarkable advances that have been made by historiography new contributions keep on appearing, which shows the variety of possibilities and approaches that can be considered when it comes to analyse this group. Focusing on our main topic, the exile turbulent political life, it can be said that new questions and new perspectives have allowed a deeper thought on the problem identification of its reality. In this way, an analyse has been established from the political culture perspective regarding the exile inner fractures which marked a part of this collective failure story during forty years (Hoyos Puente, 2012). The application of the political cultures theory enabled a penetration into the speeches and imaginaries analyse that shaped the human action of the exiled group (Sierra and Pérez Ledesma, 2010). This analytical theory, not that original any more among the Spanish historians, led to a more exhaustive approach concerning the problems dividing the different political organisations that formed the anti-Franco universe in the exile.

Born in 1931, the whole Republican State had to exile in 1939: executive, legislative and judicial powers, autonomous region institutions, political parties that supported the Second Spanish Republic democratic regimen, and a meaningful part of its citizens. Nevertheless, these institutions were a house divided against itself when they crossed the Spanish border. Regarding the continuity of these institutions after presudent Azaña's resignation and Casado's coup d'état, the triggered disputes impeded them, as 
the legitimate Republican State in exile, from playing any significant role in the complex and international Second World War scenario. The Republican institutions in exile existed uninterruptedly trying to claim the Spanish democratic representation during almost forty years of dictatorship (Valle, 1976; Sánchez Cervelló, 2011). Opposite to these institutions parallel future projects and alternative speeches were articulated by a good part of the Spanish political groups. Even when all of them had the end of dictatorship and the earliest return to Spain as their main goal, the strategies, projects and hopes of these political groups were opposed, leading them to the inability to reach any long term agreement or any common objective. Synthetically, this paper aims to tackle the reasons explaining this reality by studying the roots of these political cultures, which came together when supporting the Republican legitimacy on July 1936, but became irreconcilable enemies in the exile.

In order to accomplish this task some previous considerations need to be made. First of all, it has to be appointed that the different political cultures came from traditions and imaginaries having diverse origins, most of them developed against the Bourbon Restauration regimen. These political cultures were originated as opposition instruments having different considerations about the future, as it is shown by its crystallization in diverse political and union organizations. In the second place, it has to be said that not all political cultures fitted into the Second Republic political experience, and they only came together around the temporary pact meant by the Spanish Popular Front, as an emerging opposition instrument to the "two black year's period" of conservative policies. This alliance was at its tightest when the military uprising of July 1936 took place, however, opposite projects related to different priorities and war handling were soon made evident. On the one hand, gathered at the Republican parties and at a wide sector of the Socialist party (PSOE), reformist political cultures found themselves overwhelmed by the war situation. On the other hand, revolutionary political cultures, anarchists and specially communists, grew exponentially creating a new balance of forces among the Spanish left-wing organisations at that time. Personal disagreements during war times played also in exile an important role quite hard to weight from a rational perspective.

In third place, it has to be appointed that game rules changed after the Republican defeat and the exile. It is not easy to clearly establish if changes were deep enough to make us consider the appearance of new political cultures as a hybridisation of the existing ones. In this sense "Negrinismo" and "Prietismo" are hard to explain. Both experiences were generated by two characters with similar ideology until the Spanish civil war outbreak. Nevertheless, they represent two different and radically opposed political projects that brought together exiles from all sources. Outside Spain, a different political time was marked by personal disagreements and political party's splintering. Discrepancies about the final defeat responsibility and the chances concerning Republican insti- tutions continuation in exile served as a breeding ground for inner divisions to grow. The assembling concepts of every political culture, such as State, Nation or Citizenry, became more and more incompatible given the interpretation about past and future that different exiled groups made. Each of these political groups or subgroups searched its path independently, they created its own story to explain what happened and they also imagined their own project for the future in order to accomplish their common goal: ending with Franco's regime and returning to Spain. At the earliest stages, given the absolutely material scarcity of most of exiles, controlling the refugees helping organizations became a cause of political struggle as they counted on Republican monetary funds placed outside Spain before the end of the war (Herrerín, 2007; Mateos, 2009; Velázquez, 2014). The balance of forces was determined by this situation, especially on the key period of the Second World War, where different political positions maintained during years were shaped.

One last element that needs to be taken into consideration is the loss of efficiency experienced by the Republican institutions action and by the parties' lines in exile which, as a matter of fact, encouraged splits and usurpation of functions, most of them being more symbolic than real. Despite this situation, different inner disputes occupied a good part of the exile political life causing, in practice, inaction, fossilization and discredit among the group of exiles and also a lack of impact inside Spain on a long term basis.

From the political point of view the Republican exile went through a clearly marked variety of stages. First of them between 1939 and 1942. This early phase was definitely characterized by uncertainty, confusion and a lack of definition that could not put an end to division among organisations. Overcoming the suffering collective trauma and healing personal wounds and weaknesses, all of them derived from the need of rebuilding a new life even on a temporary basis, were facts that contributed to unbalance the dynamic itself. The political organization structures were constantly called into question generating centrifugal tensions in most cases. Furthermore, leaders strengthened their weight as a result of the organizational structures weakening after the war due to death, disappearance or imprisonment of most of their members. As a result parties' inner democracy gave way to a policy somehow imposed from upper echelons. Despite the efforts made to gather refugees together, disputes and divisions contributed to diminish exiles attendance to parties' sociability places. Alternative ways and places to keep on talking about Spain and its war were sought. This phase is marked by the civil war speech extension, based on dictatorship and brutal repression denounces, which prevented any coherent strategy from being set into motion.

Since 1942 political cultures fought about gaining the hegemonic control over the exile. Republicans got up courage and sought for unity as the URSS and the USA entered the Second World War. Political forces regrouped following the "Juntas" example: "Junta Española de Liberación" (Spanish Freedom Board) and "Junta Suprema de Unión 
Nacional" (National Union Supreme Board). Both models representing different concepts regarding the unity of action and the current strategy leading to an early return to Spain. The ideas about Spain's future and the country rebuilding basis were a cause of bifurcation. Nevertheless, the Board system was not successful at the international arena. On the San Francisco summit, in April 1945, most of the exile personalities realized that the only possible path to be followed was the exile institutional reorganization around a government, even if Prieto and his group will not agree to the idea. In order to reach this objective relations among the existing institutions had to be restored, and Mexico will be the place meeting the required conditions for it. After the session of Cortes (Spanish parliament) Negrins'government was replaced by a large government of national unity known as the "government of hope" in august 1945. Even though Negrin's government had been called into question, his executive work was implicitly acknowledged with this act.

Worth to mention, although insufficient, were Giral' efforts during his two years as president of the Republican government in exile. He got the United Nations to pass a resolution recommending the ambassadors withdrawal from Spain, considering that Franco's government was fascist and imposed by force to the Spanish people with the Axis Powers support. However, this was not enough to the eyes of Prieto's moderate socialism. Prieto's perception about the Republican government coming to a dead end and his claim to explore new channels disappointed the socialist executive settled in Toulouse, as the Republican legitimacy was once again questioned. Prieto managed to get the socialist ministers to abandon their places in the government which fostered Giral's resignation. The bustling 1940s last years were marked by Prieto's Republican scepticism and his firm commitment to reaching a pact with Monarchists, in order to articulate Spain's future by means of a plebiscite. Prieto's proposal was based on his personal conviction, as he understood that including Monarchists was required to gain the international support of the Allied Powers, especially Great Britain.

While they lived in hope of coming back to Spain, personal fractures, friendship breakups and increasing distances were the result of the political organisation struggle in order to impose each one's alternative to the others. From 1946 onwards the uncertain unity of action that made institutions gathered around blew up. Indalecio Prieto's strategy in order to come back to Spain was swept when the Cold War started and the meeting between Franco and Juan de Borbón took place in 1948. From 1950 the Republican institutions discredit in addition to Franco's Spain inclusion within the international organizations contributed to spread a general demoralization among the Republican exile group.

During the fifties neither the international circumstances, neither the internal situation of Franco's every day more consolidated dictatorship seemed to leave some room for the exile political action. Disputes grew drowsy without losing their starting points. Even if agonizing Re- publican institutions kept existing in exile while political projects fossilized in poor attended assemblies. Those ones being on the right track focussed on the inside Spain, the ones being on the wrong track stayed on the sidelines, deep in sadness, despair and obscurity. Despite all this, some exiles never ceased looking for alternatives. Whether under the form of Europeanism during the sixties, which stimulated the Munich Conversations and the encounter with the internal opposition, or by means of revitalizing the Republican institutions during the seventies, the efforts for being present in the post-Franco Spain remained a fixed value for those who politically managed to survive outside their homeland (Hoyos Puente, 2014).

\section{OPPOSED METHODS FOR THE RETURN}

Spanish exiles built up during forty years political projects and strategies in order to end with Franco's dictatorship and to come back to a democratic Spain (Heine, 1983). Most of these projects remained theoretical proposals shown throughout speeches and publications away from the praxis ground. Abstract projects imagining the future of an advanced democracy within the western world. It would not be possible sorting a detailed list of all of them as individual proposals, full of aspects and singularities deserving a monographic and still pending exam, proliferated. However, common projects also existed. They emerged from political organizations and their splits; they were kept up over time or occasionally modified responding to special needs in order to reach tactical and momentary agreements.

Once the Spanish civil war ended the Spanish Second Republic validity remained in exile. This is a capital element emerging when exile started and it was endured during forty years. Manuel Azaña's resignation at the end of February 1939 triggered the end of the Republican defence. This fact opened a legitimacy breach within the institutions whose main consequences were the Republican supporters' radical division and the institutional collapse. Events overwhelmed any rational forecast as there was not a clear guide that could represent the democratic nation outside Spain. During the following months after the Republican defeat, debates among the exiled leaders focused on clarifying which institutions may hold the representation of the Spanish nation: either the "Diputación Permanente de las Cortes" (minimum of Spanish parliament members who shall represent the Parliamentary groups in proportion to their numerical importance), either the last democratically elected government in Spain. This confrontation between Negrin's followers and Prieto's and Martínez Barrios' supporters, established a representational crisis certainly unsolved until 1945. The Spanish exile divisions were publicly shown while other exiled European governments managed to appear with one authorised voice serving as moral guide and as spokesperson before the Allied Powers. This situation led to unilateral renounces as the ones performed by the "Consejo Nacional de Euzkadi", in the hands of Manuel de Irujo, and the "Consejo Nacional de Cataluña", being 
controlled by Carles Pi Sunyer. ${ }^{1}$ Manuel de Irujo's constitutional draft to achieve an independent Euzkadi sought the integration of this region among the Allied Powers without taking into account the rest of the country. This plan modified the PNV's (Basque Nationalist Party) attitude, that had been loyal to the Republic through all the civil war period (Jiménez de Aberasturi, 2002). As a result of an institutional lack of frame clearly representing and integrating all the exiles, nationalists political cultures came up with these kind of proposals.

In 1942, as the European war became global, three main political projects appeared among the exiles. There were three opposing projects trying to define an effective strategy to regain democracy. The three of them went through a process of internal reorganization originating coalitions and new ways of articulating political action in exile. Depending on its implementation level, organizational ability and dissemination each of these projects experienced a unique development. Even if these three projects maintained a deliberate struggle for the exile hegemony, it has to be said that there were also other projects who reached a minor theoretical and organizational level but presented some elements worth to be examined (Hoyos Puente, 2013). Deeply rooted in ARE, "Acción Republicana Española", the first of these three main projects tried to gather together the liberal-republican organizations which conformed the liberal-republican culture in exile. They were firmly committed to defend the Republic existence represented by the "Diputación Permanente" and having Martínez Barrio as president (Duarte, 2009). Socialist reorganization around Indalecio Prieto's leading figure and Pablo Iglesias' Cultural Circle in Mexico was at the origin of the second of these projects. They were committed to finish any connexion to the Republican past and to seek a solution by means of a plebiscite in accordance with Monarchists. A temporary government chosen by ballot would organise political life in Spain and would also open a new political era disconnected from Republican democratic past times. Finally, the third project in contest included a variety of different political perspectives with a shared origin as all of them stood for the Republican institutions continuation represented by Juan Negrin's government. This last group had the sporadic support of the PCE (Spanish Communist Party) who developed a bit of an erratic political strategy during the forties.

Having opposing ideas about concepts such as "Nation", "Citizenry" or "Sovereignty", this three projects build up three alternatives during the forties. At the beginning Martínez Barrios' group stood for a republican restoration which would be examined afterwards on its institutional structure. Social democracy preferred a solution coming out from a plebiscite that counted on the Monarchist support, and placed the political centre as main axe of the new state structure. Defending the Spanish Popular Front agreement's validity and the institutional continuation incarnated by Juan Negrín was the option taken by the "negrinismo".

As it has been mentioned before, two other political projects defined by nationalist organisations and anarcho- syndicalism can be found on a second level of development. On the one hand, even if the nationalist liberaldemocratic political culture had quite a lot of elements in common with Acción Republicana Española's culture, its ideas about concepts such as "nation" and "citizenry" were different. This is to be at the origin of a confederal State project, as a previous stage for gaining independence. On the other hand, the libertarian labour movement also participated from a confederal state conception based on municipalism, at least on paper. Evidence of certain federalist tradition from Pi y Margall can be found in this conception, as this federalism had fed an important part of the Spanish anarco-syndicalysm (Alaiz, 1993; Herrerín, 2004). Other projects can be found beyond these organisations, as the one represented by the "institucionistas" gathered in Havana at the Conference of the Spanish Abroad University Professors Union (Ruiz-Funes, 1996; López Sánchez, 2013; Hoyos Puente 2016). In any case, as they struggled over time, analysing the three main projects becomes necessary in order to find out the keys to disagreement among them.

First of all, it needs to be said that none of these three projects put enough thought into how to evict Franco from the power he hold unlawfully as war trophy. As they were considering institutional legal incorporation in a future democratic Spanish state, they were omitting the first step, which was putting an end to Franco's regime. The trust displayed on the Second World War context since 1942 may only be explained taking into consideration the obscurity of events related to the Spanish civil war, and the abandonment of the Republican cause by the Allied Powers. According to Martínez Barrios' thought, coming back to Spain in full liberties was inevitably related to the allied victory in the Second World War. In his opinion, Franco itself or his dictatorship would not be able to survive even if his neutrality during war was to be taken into account. The Spanish people would break their chains and, in that moment, the exiles themselves would return to Spain and correct the mistakes made during the Second Republic (Martínez Barrios, 1942).

In the second place, the lack of agreement concerning the institutions' continuation in exile has to be highlighted as it represented a major obstacle. Strengthened by controlling most parts of the exile funds, Prieto's group considered the Republican institutions worthless but valid when they came to serve their own purposes, focused on funds controlling through the Diputación Permanente's delegation in the JARE. If the other two groups recognized the Republican institution's validity to be the best mechanism in order to defend the Second Republic legal continuation, nevertheless, they presented a different perspective about the past. Martínez Barrio's group believed that the Spanish Popular Front had been a mistake, as it led to establish alliances with organizations whose main goal was destroying some of the liberal ideas in which their political essence was based. ${ }^{2}$ Negrin's supporters stood by the Spanish Popular Front's importance and validity. This alliance should be kept in exile as unequivocal proof of the Spanish people wishes because they supported the Republican cause during war. 
Having different perspectives about the past impeded agreements to be reached. In order to establish a common strategy, this was as harmful as antagonisms and personalized leaderships' weight issued from last war months. Besides these two elements, it has to be said that the three projects presented incompatible factors regarding Spain's future definition. Both, government and State's conformation, were highly discussed. All perspectives got mixed up inside political projects: centralism supporters, federalists, confederates and even pro-independence. If Prieto's group was not in favour of seeking for a federal perspective to solve the Spanish situation, inside Negrin's group a variety of inclinations could be found. Regarding the Republicans, and despite the large number of Jacobins among its members, federalism became a constant demand throughout their speeches and political actions. Another element being source of disagreement was the future role of the working class. In the past, Prieto and Martínez Barrio were very critical about union's demands. Both agreed that workers' legitimate aspirations must be subordinated to the general democratic cause (Martínez Barrio, 1942; Prieto, 1942). It was therefore surprising how insistently Indalecio Prieto and his closest circle supported the idea that unions should be subordinated to a common will personified by a democratic government. This approach created a clear distance with the labour imaginary shared by Largo Caballero's followers and the Socialists supporting Negrín. Under Prieto's consideration, citizens' rights should be put ahead of workers' rights, as he thought that socialist revolutionary drift from 1933 was a terrible episode that should not ever be repeated.

Opposite to that idea, Negrin's circle did only not deny worker's role but, on the contrary, it acclaimed workers as main bastion of the Republican legality defence. This discourse was strengthened when the PCE temporary supported Negrín's group. However, this quality it is always to be found in this group as, inside Socialism, Negrín supporters' thesis were based on figures as Ramón Lamoneda and Ramón González Peña, both representing in exile the closest members to the labour movement, even before and after they were expelled in 1946. This was a key issue throughout the time these three political projects managed to exist. Despite the fact that all three were having the category "Citizenry" as central, the meaning was different for each one of them. According to Prieto's supporters and Martínez Barrios'circle, "People" meant citizenry however, as far as Negrín's followers were concerned it mainly referred to the working class. Beyond these elements for disagreement, it has to be highlighted another common factors that gathered groups together, as the economical country organization or the need to establish a strong state secularization, which was the only possible way that freedom of religion and worship could be guarantee. All of them agreed, considering the State as an economy key piece carrying out a strongly interventionist policy, in order to allow an economical democracy, essential to the existence of a real political democracy. Respecting private initiative most groups stood for establishing a system where the country main activity sectors, even banking, remained under public control. An efficient fiscal policy should regulate private activity in order to get redistribution of wealth. This fact would end Franco's extended practise based on capitalism among friends (Gómez Herráez, 2000). Despite the common background, a general agreement was never reached.

From fifties onwards all three positions started declining due to several reasons. Concerning Negrin's group, its leader political inhibition was an element hard to overcome despite the attempts carried out by its true supporters, such as Álvarez del Vayo, Lamoneda, Tomás Bilbao or Antonio Velao, who tried to maintain a spirit more and more distanced from Negrin's ideology. Not to mention that this group always had as a unique aspect its restraint from its leader thesis. Martínez Barrio's symbolical role as president of the exiled Republic, and the institutions loss of strength, after Giral and Llopis government failures, made his existence to be more anecdotal than real. Finally, Prieto was undermined as a result of the unsuccessful negotiations with Monarchists (Cabezas, 2005; Mateos, 2008). The three projects final decline arrived with their leader's death: Negrín died in 1956, and Martínez Barrio and Prieto passed away in 1962.

From sixties onwards the only possible solution regarding the exiled political organizations' survival was coming into contact with the opposition sectors emerged inside Spain. Doubtlessly, the PCE was first realizing this fact, whose consequence was the 1956's doctrine concerning National Reconciliation. Being under Llopis control in Toulouse, the PSOE faced more troubles finding an active policy in order to revitalise the party itself inside Spain (Vargas, 1999). Nevertheless, Republicans were the ones facing more difficulties in doing so. After the party's reconstruction into ARDE in 1960, Republicans started to establish strong ties with Spain's inside on the seventies. Their unbreakable Republic commitment impeded them from participating in the Spanish Transition (Hoyos Puente, 2014).

These political organizations revitalized during the seventies. They were eager to restart their activity with the intent to gain political influence in a scenario free of Franco. The Republican government in exile, counting on Luis Echeverria Mexican government' support, tried to exercise influence on having the Republic back to power in Spain, but in a way more symbolic than real. This was done by political organizations too which caused severe tensions inside the PSOE and the PCE, and whose main consequence was having the reformers and the ones more attached to orthodoxy starring ruptures and rifts. Despite all the efforts made in order to regain political activity, both PSOE and PCE were not themselves. Their political cultures had been substantially modified (Andrade Blanco, 2012). Concerning PSOE's case it was due to a generation fracture where young people from inside Spain starred in. Not to mention that most of them were not connected to the traditions that shaped Pablo Iglesias' party. Regarding PCE's situation main problem was related to the old leaders' inability to readjust to a new reality that could not be understood after being away from their country during forty years. 


\section{THE REASONS FOR FAILURE}

Republican defeat at the Spanish civil war meant the political fracture of the Spanish left-wing groups. Once being expelled from power and the country itself these groups started a reflexion process about what happened. Moreover, they tried to elaborate once again their hopes and strategies seeking the earliest return to Spain. War reservations and disputes helped political organization speeches to take different paths. Groups took refuge in programs reflecting their top aspirations based on the key elements that had shaped the diverging imaginaries. From this perspective different State proposal were defined. Even if democracy and freedom were distinguishing marks shared by all exiles they came up to with opposing political projects and dissimilar strategies. Despite the continuous appeals for unity of action the existing differences, as well as the personal disputes carried by the leaders since 1939, were key on creating solid working alliances in order to obtain the long-awaited end of Franco's regime.

Therefore debates were of such an intensity that impeded open wounds from healing and a coordinated and joint answer from being built. This would had provided one voice to exile in order to be heard in the inside Spain and specially to be heard by the Allied Powers. Even if the Republican exile never gave up the fight, after the Second World War and without the Allied Powers' support, both Spain and themselves missed the European anti-Franco beneficial train which made them suffer through decades one of the most repressing dictatorships from the twentieth century.

An ideological isolating long period fostered by the lack of contact with the Spanish reality was experienced by exiles. Ignoring the Spanish society evolution the exiles faced the Spanish Transition without enough tools in order for them to be politically relevant. Their political cultures had suffered from a fossilization process which impeded them to overcome the common trauma experienced abroad. As usually happens in long-term exiles the Spanish Republicans' unlikely possibility to experience a complete return became a concrete reality due to several elements. First of all, the most politicized sectors found it hard to bear the loss of prominence in the Spanish political arena. In the second place, it was quite hard to understand that Spain itself had changed under Franco's dictatorship. Neither the exiles' analysis, neither their top political aspirations were taken into account, despite the fact that a part of them had not lost any undeniable political value. Finally, the lack of a common public policy concerning the exiles reintegration, either as active political agents, either as democratic fighting heroes, impeded them from a full social incorporation (Guinsberg, 1989).

Among all the proposals born in exile Indalecio Prieto's was the one getting closer to the Spanish Transition final result, excluding the plebiscite. Monarchy as a way of government was chosen by Franco himself and the parliamentary form was developed as an intermediate formula as a result of a pact where exiles had little represen- tation but Santiago Carrillo. The exile political cultures could not return to the democratic Spain, which impoverished substantially the Spanish left-wing forces. Above all, generated debates and reflections during exile can be seen as source of inspiration and as a part of the Spanish left-wing tradition.

\section{ACKNOWLEDGEMENT}

This paper was possible thanks to the research project entitled "Federalismo, Estado y nación en Europa del Sur y América Latina en la época liberal, una perspectiva comparada". ID reference: HAR2013-35245.

\section{NOTES}

1 "Declaración conjunta de los Consejos Nacionales de Cataluña y Euskadi al ministro de Estado inglés", 18 de enero de 1941, Archivo Carlos Esplá, 5.3/5142-a. Centro de documentación de la Memoria Histórica. Salamanca.

2 Continuous messages claiming the impossibility of a pact reedition as the Popular Front, legally void in 1940 but long before buried, are to be found in ARE's Central Board notifications to different delegations. See the $9^{\text {th }}$ of August, 1941 Martínez Barrios' statement. Archivo Carlos Esplá, 5.2/5077.

\section{REFERENCES}

Alaiz, Felipe (1993) Hacia una federación de las autonomías ibéricas. Ediciones Madre Tierra, Madrid.

Andrade Blanco, Juan Antonio (2012) EL PCE y el PSOE en la Transición. La evolución ideológica de la izquierda durante el proceso de cambio político. Siglo XXI, Madrid.

Cabezas, Octavio (2005) Indalecio Prieto. Socialista y Español. Algaba, Madrid.

Duarte, Ángel (2009) El otoño de un ideal. El republicanismo histórico español y su declive en el exilio de 1939. Alianza Editorial, Madrid.

Gómez Herráez, José M. ${ }^{a}$ (2000) Economía y posguerra desde el exilio. Universitat Jaume I, Castellón.

Guinsberg, Enrique (1989) «Problemática psicosocial del exilio». In Consecuencias psicosociales de las migraciones y del exilio, coords. Casalet Ravena, Mónica and Comboni Salinas, Sonia. Universidad Autónoma Metropolitana, Unidad Xochimilco, México: 17-31.

Heine, Hartmut (1983) La oposición política al franquismo. Crítica, Barcelona.

Herrerín, Ángel (2004) La CNT durante el franquismo. Clandestinidad y exilio (1939-1975). Siglo XXI, Madrid.

Herrerín, Ángel (2007) El dinero del exilio, Indalecio Prieto y las pugnas de posguerra (1939-1947). Siglo XXI, Madrid.

Hoyos Puente, Jorge de (2012) La utopía del regreso. Proyectos de Estado y sueños de Nación en el exilio republicano en México. El Colegio de México-Universidad de Cantabria, México DFSantander.

Hoyos Puente, Jorge de (2013) «El pensamiento político en el exilio» In Pensamiento político en la España Contemporánea, eds. Menéndez Alzamora, Manuel and Robles Egea, Antonio. Trotta, Madrid: 599-626.

Hoyos Puente, Jorge de (2014) «Las limitaciones de la Transición española. El imposible retorno de los republicanos de ARDE, los casos de Victoria Kent y Francisco Giral». Historia del Presente, 23: 43-53

Hoyos Puente, Jorge de (2016) ;Viva la inteligencia! El legado de la cultura institucionista en el exilio republicano. Biblioteca Nueva, Madrid.

Jiménez de Aberasturi, Juan Carlos (2002) «Irujo en Londres, 19391945». Vasconia, 32: 99-132. 
López Sánchez, José M. ${ }^{\text {a }}$ (2013) Los refugios de la derrota. El exilio cientifico e intelectual republicano de 1939. CSIC, Ed. Catarata, Madrid.

Martínez Barrio, Diego (1942) Discurso en el Centro Español de México, 30 mayo de 1942. Ed. A. Artis, México DF.

Mateos López, Abdón (editor) (2008) Indalecio Prieto y la política española. Fundación Pablo Iglesias, Madrid.

Mateos López, Abdón (2009) La batalla de México. Final de la Guerra Civil y ayuda a los refugiados, 1939-1945. Alianza Editorial, Madrid.

Prieto Tuero, Indalecio (1942) Confesiones y rectificaciones. Círculo Cultural Pablo Iglesias, México.

Ruiz-Funes, Concepción (1996) «La Unión de Profesores Universitarios Españoles en el Exilio. Motivos y razones». In AA. VV. Los Refugiados españoles y la cultura mexicana. Actas de las segundas jornadas celebradas en El Colegio de México en noviembre de 1996. El Colegio de México, México: 435-449.

Sánchez Cervelló, Josep (2011) La Segunda República en el exilio (1939-1977). Planeta, Barcelona.

Sierra, María y Pérez Ledesma, Manuel (editores) (2010) Culturas políticas: Teoría e historia. Instituto Fernando el Católico, Zaragoza.

Valle, José M. ${ }^{a}$ del (1976) Las instituciones de la República española en el exilio. Ruedo Ibérico, París.

Vargas, Bruno (1999) Rodolfo Llopis (1895-1983) Una biografia política. Planeta, Barcelona.

Velázquez Hernández, Aurelio (2014) Empresas y finanzas del exilio. Los organismos de ayuda a los republicanos españoles en México (1939-1949). El Colegio de México, México DF. 